\title{
Diagnosis of a Case of Ectopic Parathyroid Adenoma on the Early Image of ${ }^{99 m}$ Tc-MIBI Scintigram
}

\author{
TAKAKO MORIYAMA****, KAZUNORI KAGEYAMA*, TAKESHI NIGAWARA*, MASASHI KOYANAGI**, \\ IKUO FUKUDA**, HITOSHI YASHIRO*** AND TOSHIHIRO SUDA* \\ *Department of Endocrinology and Metabolism, Hirosaki University School of Medicine, 5 Zaifu-cho, Hirosaki, Aomori 036-8562, \\ Japan \\ **First Department of Surgery, Hirosaki University School of Medicine, Aomori 036-8562, Japan \\ ***Third Department of Internal Medicine, Odate Municipal Hospital, 3-1 Yutaka-cho, Odate, Akita 017-8550, Japan
}

\begin{abstract}
We report the case of a 64-year-old woman who had a severe hypercalcemia. Serum calcium, intact parathyroid hormone $(\mathrm{PTH}), 1 \alpha, 25(\mathrm{OH})_{2}$ vitamin $\mathrm{D}_{3}$ levels were all elevated, and serum phosphorus level was decreased, which were all consistent with primary hyperparathyroidism (PHPT). ${ }^{201} \mathrm{Tl} /{ }^{99 \mathrm{~m}} \mathrm{Tc}$ subtraction scintigraphy failed to detect any abnormal accumulation in the neck and chest, while ${ }^{99 \mathrm{~m} T c-M I B I}$ scintigraphy demonstrated the focal accumulation of increased radiotracer uptake in the mediastinum only on the early image, but not on the delayed image. Neck and chest computerized tomography scanning showed a small nodule at the retrosternal region, and a selective venous sampling study of the intact PTH suggested PTH production from the nodule. Together with the observation of the early image of ${ }^{99 m}$ Tc-MIBI scintigraphy, it was diagnosed that the patient had an ectopic parathyroid adenoma. Video-assisted thoracic surgery was performed. A 15-mm diameter mass, visualized by an intravenous infusion of methylene blue, was excited. The histopathology was consistent with the parathyroid adenoma. The adenoma was composed of mainly chief cells and rarely oxyphil cells. The absence of oxyphil cells would explain the lack of ${ }^{99 \mathrm{~m}} \mathrm{Tc}-\mathrm{MIBI}$ retention on late-phase imaging in our case. Even without uptake on the delayed image of ${ }^{99 \mathrm{~m}}$ Tc-MIBI scintigram, the early image was available for the localization of an ectopic parathyroid adenoma.
\end{abstract}

Key words: Primary hyperparathyroidism, Intact PTH, Calcium, ${ }^{99 \mathrm{~m}} \mathrm{Tc}-\mathrm{MIBI}$ scintigram, Venous sampling

(Endocrine Journal 54: 437-440, 2007)

PRIMARY hyperparathyroidism (PHPT) is a common endocrine disease characterized by hypercalcemia with an excess secretion of parathyroid hormone (PTH) [1]. PHPT is caused by mainly adenomatous, or hyperplastic glands [2]. Patients with PHPT tend to suffer from complications such as reduction of bone mineral density, nephrolithiasis and gastric ulcer, which may impair their quality of life $[1,2]$. For the management of PHPT, parathyroidectomy of the abnormal gland is the most effective treatment. Different imaging techniques, such as high resolution ultrasonography (US),

Received: September 20, 2006

Accepted: February 2, 2007

Correspondence to: Kazunori KAGEYAMA, M.D., The Third Department of Internal Medicine, Hirosaki University School of Medicine, 5 Zaifu-cho, Hirosaki, Aomori 036-8562, Japan computerized tomography (CT), arteriography, venous sampling, and magnetic resonance imaging, have been used for detection of the abnormal parathyroid glands $[3,4]$, although, diagnostically, they are of limited value when it comes to detecting the hyperfunctioning glands [5].

Radionucleic procedures have been also involved in the detection and localization of parathyroid adenomas. Technetium-99m-methoxyisobutylisonitrile ${ }^{99 \mathrm{~m}} \mathrm{Tc}$ MIBI) has been used for preoperative evaluation of PHPT [6]. In 1992, Taillefer et al. proposed a doublephase (early and late) protocol to capitalize on the faster clearance of ${ }^{99 \mathrm{~m}} \mathrm{Tc}-\mathrm{MIBI}$ from the normal thyroid tissue for better visualization of parathyroid adenoma or hyperplasia [7]. While a double-phase ${ }^{99 \mathrm{~m}} \mathrm{Tc}-\mathrm{MIBI}$ scintigraphy has a high sensitivity to detect abnormal glands [7], recent reports suggest that this technique 
(A)

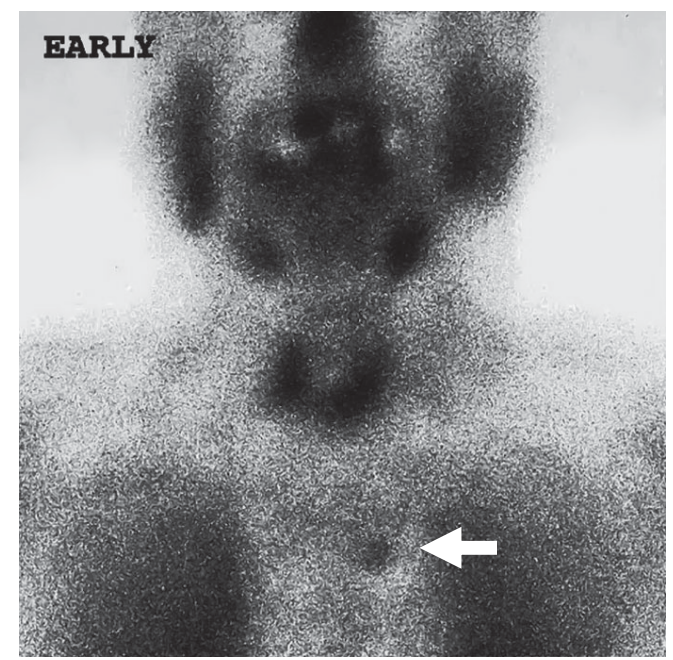

(B)

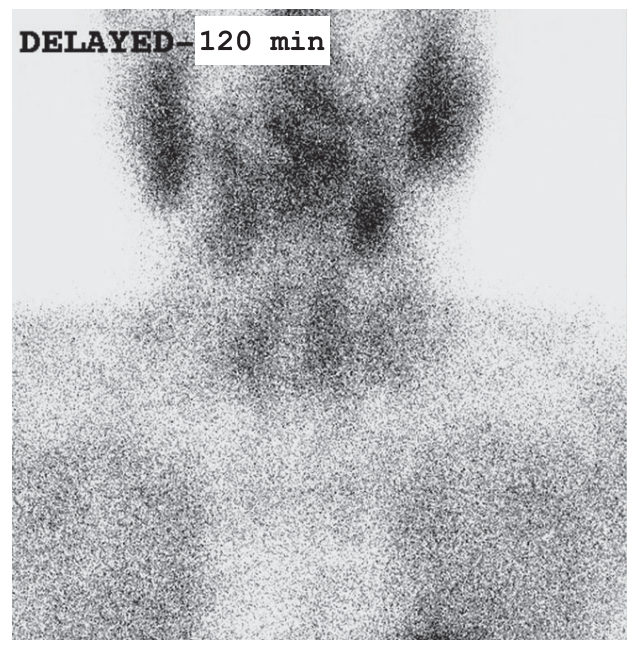

Fig. 1. ${ }^{99 \mathrm{~m} T c-M I B I}$ scintigram of the patient. (A) The scintigram on the early image reveals an increased focal accumulation of the radioisotope in the mediastinum (a white arrow). (B) The scintigram on the delayed image ( $2 \mathrm{~h}$ ) does not clearly show the focal accumulation.

might induce a false negative or positive case [8-10], because of certain factors that influence the uptake and clearance of ${ }^{99 \mathrm{~m} T c-M I B I}$ [11-13].

An ectopic parathyroid adenoma is also caused PHPT. However, it is too difficult to detect by various imaging modalities, because ectopic parathyroid adenomas are usually small [14]. Therefore, ectopic parathyroid adenomas are often detected either in the preoperative work up of patients who present with hypercalcemia or in post-parathyroidectomy patient with persistent hypercalcemia [15]. A few reports demonstrate that an early imaging of dual-phase ${ }^{99 \mathrm{~m}} \mathrm{Tc}-\mathrm{MIBI}$ scintigraphy is a pitfall to diagnose abnormal parathyroid adenomas located in the neck [11, 12], while only one paper reported the usefulness of early imaging in an ectopic adenoma [15].

We report here another case of PHPT due to an ectopic parathyroid adenoma, detected only on the early image of dual-phase ${ }^{99 \mathrm{~m}} \mathrm{Tc}-\mathrm{MIBI}$ scintigraphy, but not on the delayed image.

\section{Clinical Summary}

A 64-year-old woman with a severe hypercalcemia was referred to our department for further evaluation of PHPT. Her serum calcium $(12.3 \mathrm{mg} / \mathrm{dl})$, intact PTH $(226 \mathrm{pg} / \mathrm{ml}), 1 \alpha, 25(\mathrm{OH})_{2}$ vitamin $\mathrm{D}_{3}(85 \mathrm{pg} / \mathrm{ml})$ con-

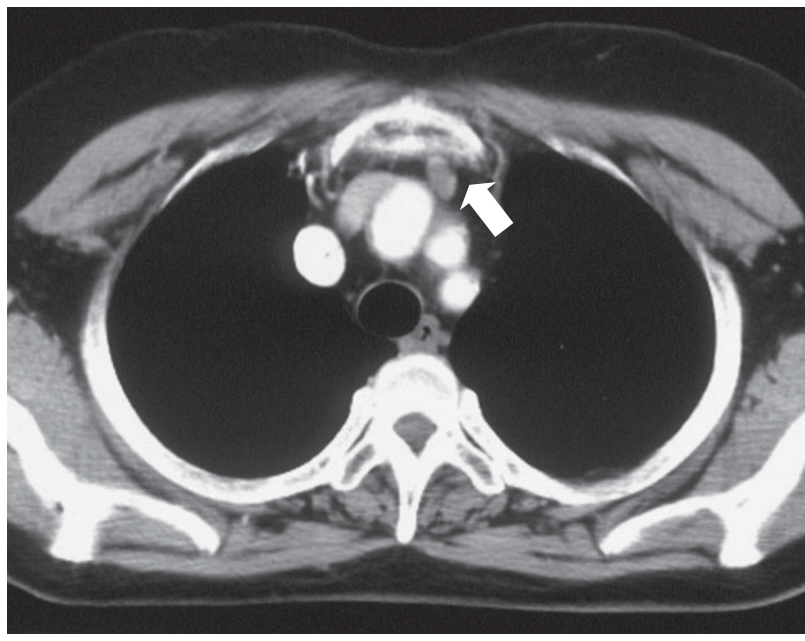

Fig. 2. CT scannings of the chest. The scanning shows a small nodule (15 mm transverse diameter) at the retrosternal region and in the anterior left of the brachiocephalic artery (a white arrow).

centrations were all elevated, serum phosphorus level $(2.1 \mathrm{mg} / \mathrm{dl})$ was decreased, and PTH-related protein level $(0.3 \mathrm{pmol} / \mathrm{ml})$ was within normal limits. T-score of her femoral bone mineral density was $-1.5 .{ }^{201} \mathrm{Tl} /$ ${ }^{99 \mathrm{~m}} \mathrm{Tc}$ subtraction scintigraphy failed to detect any abnormal accumulation in the neck and chest. ${ }^{99 m} \mathrm{Tc}-$ MIBI scintigraphy demonstrated the focal accumulation of increased radiotracer uptake in the mediastinum 


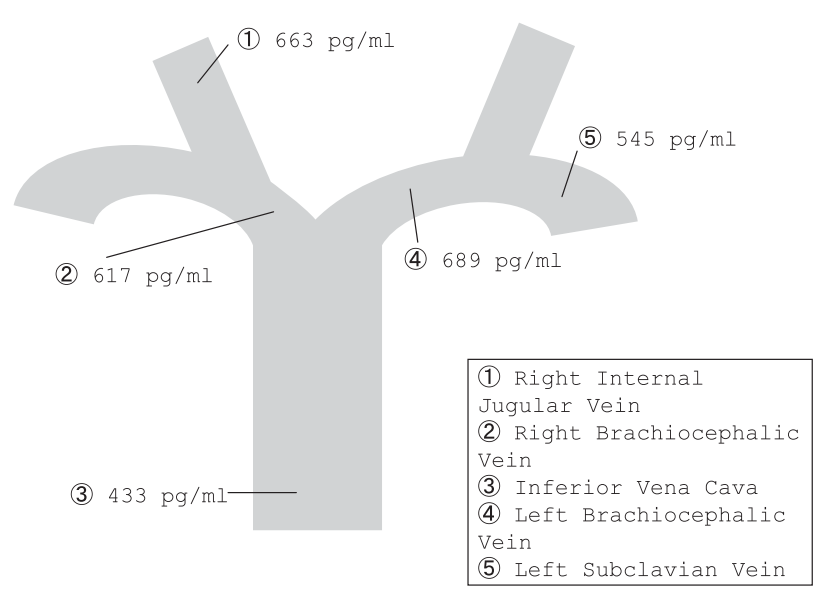

Fig. 3. Venous sampling study of intact PTH. The study shows that intact PTH levels are increased in the left brachiocephalic vein.

(A)

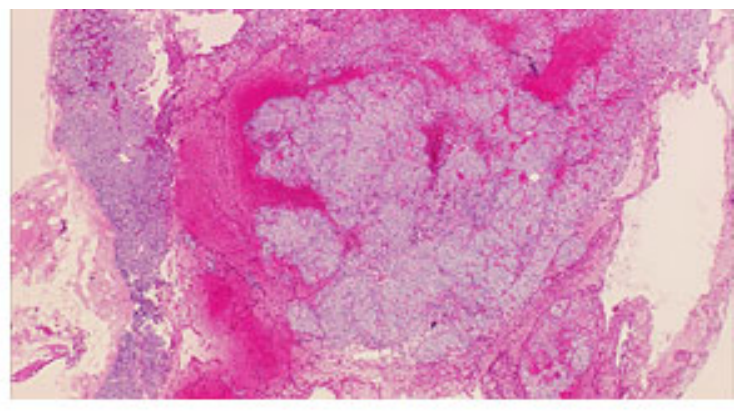

(B)

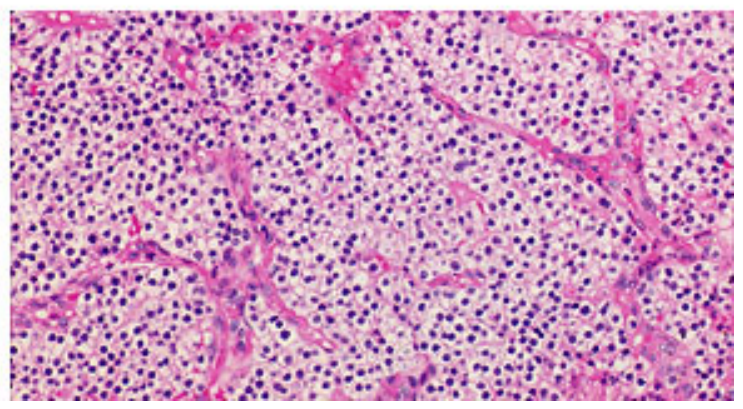

Fig. 4. Hematoxylin-eosin stained sections of the adenoma (original magnification $\times 40(\mathrm{~A})$ and $\times 400(\mathrm{~B})$ ). The tumor was histologically identified with a parathyroid adenoma. The adenoma was composed mainly of chief cells and a few oxyphil cells, covered with a fibrous capsule (B).

only on the early image, but not on the delayed image (Fig. 1). The enhanced CT scanning of the chest showed a small nodule ( $15 \mathrm{~mm}$ transverse diameter) at the retrosternal region (Fig. 2). To further examine the existence of an ectopic parathyroid adenoma, a selective venous sampling study of intact PTH was per- formed. As shown in Fig. 3, intact PTH levels were increased in the left brachiocephalic vein. Videoassisted thoracic surgery was performed. A $15-\mathrm{mm}$ diameter mass, visualized by an intravenous infusion of methylene blue, was found and excited. Histopathology was consistent with parathyroid adenoma. The adenoma was composed mainly of chief cells and a few oxyphil cells, covered with a fibrous capsule (Fig. 4). Soon after the operation, the patient's elevated calcium and intact PTH levels were transiently decreased, and then normalized.

\section{Discussion}

${ }^{99 \mathrm{~m} T c-M I B I}$ scintigraphy is accurate, and produces images of higher quality [6]. The typical pattern in the parathyroid adenoma demonstrates a prolonged retention of ${ }^{99 \mathrm{~m} T c-M I B I}$ in the adenoma with a rapid washout of the tracer from the normal thyroid tissue. The size of tumor, oxyphil cell contents, cell cycle phases, serum calcium levels, and P-glycoprotein expression levels have been discussed as contributing factors [13]. Mitochondrial density in the adenoma is also a major factor to cause a prolonged retention of ${ }^{99 \mathrm{~m}} \mathrm{Tc}$, because the number of mitochondria is significantly higher in lesions detected by scintigraphy than in those that were missed, and the highest ratio of mitochondria per cell has been found in oxyphil cells [16].

Benard et al. reported a case of rapid ${ }^{99 \mathrm{~m} T c-M I B I}$ clearance from a parathyroid adenoma [11]. They hypothesize that mitochondria-rich oxyphil cells make a logical target for the prolonged retention of ${ }^{99 \mathrm{~m}} \mathrm{Tc}$ MIBI usually observed in abnormal parathyroids. This concept is consistent with our case, because the histopathology in our case showed hardly any oxyphil cells. Although we have no idea whether most ectopic parathyroid adenomas have few oxyphil cells, it is at least possible that the absence of these cells would explain the lack of ${ }^{99 m}$ Tc-MIBI retention on late-phase imaging in our case.

In summary, we report a case of ectopic parathyroid adenoma detected on early image of ${ }^{99 \mathrm{~m}} \mathrm{Tc}-\mathrm{MIBI}$ scintigram, but not on delayed image. The absence of oxyphil cells would explain the lack of ${ }^{99 \mathrm{~m} T c-M I B I}$ retention on late-phase imaging in our case. Even without uptake on the delayed image of ${ }^{99 \mathrm{~m}} \mathrm{Tc}-\mathrm{MIBI}$ scintigram, the early image was available for the localization of the ectopic parathyroid adenoma. 


\section{Acknowledgments}

We thank Dr. Kazuhiro Kudo for helpful advice on histopathology. This work was also supported in part by Health and Labour Science Research Grants (Re- search on Measures for Intractable Diseases) from the Ministry of Health, Labour, and Welfare of Japan, and by a grant to Toshihiro Suda from the Ministry of Education, Science and Culture of Japan (No. 18591014).

\section{References}

1. Bilezikian JP, Potts JT Jr, Fuleihan Gel-H, Kleerekoper M, Neer R, Peacock M, Rastad J, Silverberg SJ, Udelsman R, Wells SA (2002) Summary statement from a workshop on asymptomatic primary hyperparathyroidism: a perspective for the 21 st century. $J$ Clin Endocrinol Metab 87: 5353-5361.

2. Bringhurst FR, Demay MB, Kronenberg HM (1998) Hormones and disorders of mineral metabolism. In: Wilson JD, Foster DW, Kronenberg HM, Larsen PR (eds) Williams Textbook of Endocrinology, $9^{\text {th }}$ edition. W.B. Saunders Company, Philadelphia, 1155-1209.

3. Krubsack AJ, Wilson SD, Lawson TL, Kneeland JB, Thorsen MK, Collier BD, Hellman RS, Isitman AT (1989) Prospective comparison of radionuclide, computed tomographic, sonographic, and magnetic resonance localization of parathyroid tumors. Surgery 106 : 639-644.

4. Bhansali A, Masoodi SR, Bhadada S, Mittal BR, Behra A, Singh P (2006) Ultrasonography in detection of single and multiple abnormal parathyroid glands in primary hyperparathyroidism: comparison with radionuclide scintigraphy and surgery. Clin Endocrinol (Oxf) 65: 340-345.

5. Lumachi F, Zucchetta P, Angelini F, Borsato N, Polistina F, Favia G, D'Amico DF (2000) Tumors of the parathyroid glands. Changes in clinical features and in noninvasive localization studies sensitivity. $J$ Exp Clin Cancer Res 19: 7-11.

6. O'Doherty MJ, Kettle AG, Wells P, Collins RE, Coakley AJ (1992) Parathyroid imaging with technetium-99m-sestamibi: preoperative localization and tissue uptake studies. J Nucl Med 33: 313-318.

7. Taillefer R, Boucher Y, Potvin C, Lambert R (1992) Detection and localization of parathyroid adenomas in patients with hyperparathyroidism using a single radionuclide imaging procedure with technetium-99m- sestamibi (double-phase study). J Nucl Med 33: 18011807.

8. Westreich RW, Brandwein M, Mechanick JI, Bergman DA, Urken ML (2003) Preoperative parathyroid localization: correlating false-negative technetium $99 \mathrm{~m}$ sestamibi scans with parathyroid disease. Laryngoscope 113: 567-572.

9. Leslie WD, Riese KT, Mohamed C (2000) Sestamibi retention in reactive lymph node hyperplasia: a cause of false-positive parathyroid localization. Clin $\mathrm{Nucl}$ Med 25: 216-217.

10. Palestro CJ, Tomas MB, Tronco GG (2005) Radionuclide imaging of the parathyroid glands. Semin Nucl Med 35: 266-276.

11. Benard F, Lefebvre B, Beuvon F, Langlois MF, Bisson G (1995) Rapid washout of technetium-99m-MIBI from a large parathyroid adenoma. J Nucl Med 36: 241-243.

12. Leslie WD, Riese KT, Dupont JO, Peterdy AE (1995) Parathyroid adenomas without sestamibi retention. Clin Nucl Med 20: 699-702.

13. Pons F, Torregrosa JV, Fuster D (2003) Biological factors influencing parathyroid localization. Nucl Med Commun 24: 121-124.

14. Ng P, Lenzo NP, McCarthy MC, Thompson I, Leedman PJ (2003) Ectopic parathyroid adenoma localised with sestamibi SPECT and image-fused computed tomography. Med J Aust 179: 485-487.

15. Vijayakumar V, Anderson ME (2005) Detection of ectopic parathyroid adenoma by early Tc-99m sestamibi imaging. Ann Nucl Med 19: 157-159.

16. Sandrock D, Merino MJ, Norton JA, Neumann RD (1993) Ultrastructural histology correlates with results of thallium-201/technetium-99m parathyroid subtraction scintigraphy. J Nucl Med 34: 24-29. 